\title{
脳血管攣縮による中膜筋細胞壞死の病理
}

\author{
山嶋 哲盛·林実*·佐藤 一史·早瀬 秀男·山本信二郎
}

\section{Pathology of Myonecrosis following Cerebral Vasospasm}

\author{
Tetsumori Yamashima, Minoru Hayashi*, Kazufumi Sato, Hideo Hayase \\ and Shinjiro YAMAMOTO \\ Department of Neurosurgery, University of Kanazawa, Kanazawa; ${ }^{*}$ Department of Neurosurgery, Fukui \\ Medical School, Fukui
}

\begin{abstract}
Histological changes of the cerebral arteries taken from 3 patients who died of cerebral vasospasm after subarachnoid hemorrhage were investigated and compared with those of 10 dogs with experimental vasospasm induced by a subarachnoid injection of $0.15-0.20 \mathrm{mg} / \mathrm{kg}$ of epinephrine.

The cerebral arteries of the human autopsy cases known to have undergone spasm exhibited a wide lumen with thin media resulting from necrosis of the smooth muscle cells. These necrotic smooth muscle cells were replaced by scattered, eosinophilic cellular debris, cspecially in the outer layer of the media. In the experimental study, the subarachnoid injection of epinephrine produced frank necrosis of the smooth muscle cells and marked dilatation of the arterial lumen, especially in 5 dogs, and was associated with hypothalamic infarctions and inflammatory swellings of small subarachnoid arteries. Dogs sacrificed artificially revcaled myonecrotic changes that were uniformly and intensely stained with eosin, whereas those of spontaneous death revealed myonccrosis similar to human autopsy cases.

It is suggested that myonecrosis might be formed as a result of prolonged, intense contraction induced by epinephrine as well as by vasoactive exudates from the hypothalamic lesions or the small subarachnoid arterics.
\end{abstract}

Key words: myonecrosis, smooth muscle cell, cerebral vasospasm, subarachnoid hemorrhage, epinephrine

\section{I はじめに}

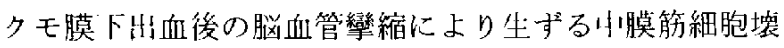
死については, Crompton ${ }^{3 !}$ 以来，臨床剖㛟例 $7,12,14$ 上奏騃 モデル1,5,16) とを刘象に詳細な病理学的梌索がなされてい

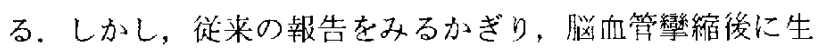
ずる中膜筋細泡壊死の程度について，臨休剖検例と奏駼飞 デルとの間に大きな差異がある，その理由は，臨床剖㛟例 には既存の動脈硬化がみられること，および従来の光顕レ
ベルで観察しうる中膜朌細胞壊死の丰娩モデルがなかった ことの 2 点である。

臨床剖椮例を対象に，脸血管攣縮後に生ずる中膜筋細胞 壊死の典型的所見初めて記載したのは Mizukami $5^{12) て ゙ ~}$ ある。一力，最近我々 ${ }^{191}$ は，エピネフリン孛雑偅成犬の視 交仪槽内八注入することにより，臨床剖检例でみられるも のに似た中膜许細胞壊死を実駼的に作製し5ること在鞁告

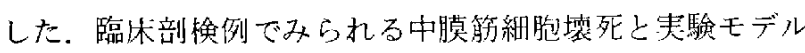
でみられるものと老比較检討寸ることは，脳血管攣樎の成

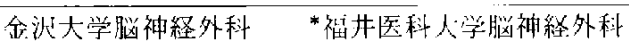

Address reprint requests to: T. Yamashima, M.D., Department of Neurosurgery, University of Kanazawa, 13-1 Takara-machi, Kanazawa 920.

受稿 1983 年10月17日 受理 1984 年 2 月20日
} 
因を知る上できわめて重要であると思われる、そこで，本 部文において両者を対比しつつ，兴血管彎縮後に生ずる中 膜筋細胞壊死を病理学的に㛟掌した。

\section{III対象および方法}

\section{1. 臨床剖検例}

我々は過去 2 年間に，クモ膜下出血に合作した兴血管攣 縮により死亡した48才女性 1 例执よび39才男性 2 例の計 3 例を経騃した。 これら 3 例に対しては, 脳室一体外ドレナ ージ以外に開頭手術はなされなかった。剖検に際しては， ウイリス輪に対するホルマリンの浸透をよくするため，流 水在注ぎタモ膜下腔の血腫を入まかに除去したのち，摘出 脳を10\%ホルマリン中で 1 邀間浸透固定した。 その後，ウ イリス輪をはずし頭蓋内起始部より皮質動脈の近位部に至

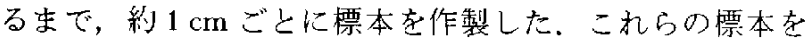
10\%ホルマリンでさらに 1 週間固定したのち脱水し，年 フィンに包埋した。薄妸は的 $5 \mu \mathrm{m}$ の厚さに行い, Hematoxylin-eosin (HE)染色を施し光学顕微鏡で観察した。

\section{2. 実験モデル}

モデル作製に際し，体重 $10 \mathrm{~kg}$ 㓩後の雑種成犬10䫓を用 いた. $50 \mathrm{mg} / \mathrm{kg}$ の nembutal (pentobarbital) を静注し，太 さ $0.8 \mathrm{~mm}$ ，長さ $70 \mathrm{~mm}$ のルンバール針により視神経管释 由で視交攴槽を穿刺した。自然落下により $2 \sim 3 \mathrm{ml}$ の腷

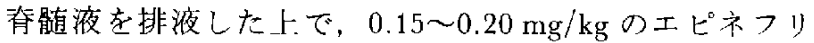
ンを用手的に注入した， 10 頭のうち 2 頭は実駼後 3 日目上 6 日目に自然死亡したため，その数洔间後に解剖を行っ た。 また，残り 8 頭は，実験後 3 日〜 8 䓢間日までに脱血 により人為的に死亡せせした。解剖に際しては，脳底部在 損傷しないよう可及的丁寧に兴在摘出した。ウイリ又輪上 周辺のクモ膜下腔とを肉眼的に観察したのち，摘计脳は 10 \%ホルマリン中で 2 週間固定し，視交齐より橋まで $3 \mathrm{~mm}$ ごとに前額断標本を作製し，脱水後パラフィンに包埋し た，標本は約 $5 \mu \mathrm{m}$ の厚さに薄切し，HE 染色を施し光学 顕微鏡により脳底部の主幹動脈と視床下部上を観察した。

\section{III 結果}

\section{1. 臨床剖検例}

\section{<症例 1>48才，女性}

臨床経過：1981年8月 8 日，突然眼前の暗黑感訴え意 識を消失し，5分後に応答が可能となったが頭痛が続くた め翌日当科に入院した，入院時，意識は清明であるが項部 強直がみられ，CTスキャンにて左シルビウス裂を中心に クモ膜下油血がみられた（Fig.1A)。家族の希望で手術を 待機していたところ，発症 1 週間目頃より意識障害 $($ II -3$)$ および5肢に強い右片麻を呈し，CTスキャンでは左中

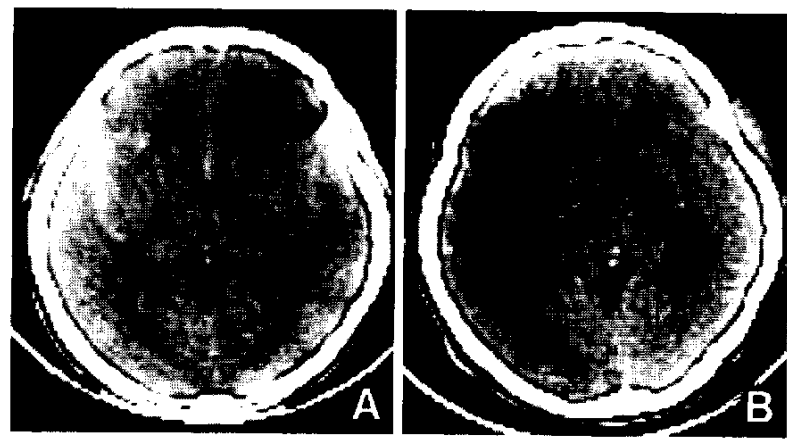

Fig. 1 GT scans in Case 1. A: On the following day atter subarachnoid hemorrhage $(\mathrm{SAH})$, a high-density area is shown in the left sylvian fissure. B: Eleven days after $\mathrm{SAH}$, a low-density area is shown in the territory of the left middle cerebral artery.

大脳動脈領域に低吸收域の出現をみたが，脳室の圧排像や 偏位はみられなかった。 8 月19日には意識障害はさらに進 行して瞳孔不同が出現し，CTスキャンでは低吸収域が掂 大し左中大脸動脈領域全体に及んでいた(Fig.1B)。 。た 左側敛室は圧排され，第三脳公は右一 $7 \mathrm{~mm}$ 偏位しており 迁回槽は両側とも消失していた。患者法しだいに四肢咽 を呈し，翌日には昏睡となり，発泟 2 週間目に死亡した。

病理所見：大脳は特に左半球が腫張しておう，左の带状 凹と鈎回のヘルニアがみられた。クモ膜下出血法，視交刃 槽の前半分と左シルビウス㤠に中等量，画側の大兴穹强部 と右シルビウス裂に少量みられ，出血源は左の内頸後交通 動脈瘤であった。割面をみると，左中大脳動脈領域では軟 化が強く，脳幹に二次的な出血がみられた。中膜筋細胞壊 死は，左中人脳動脈で高度に(Fig. 2)，また湈側前大脳動

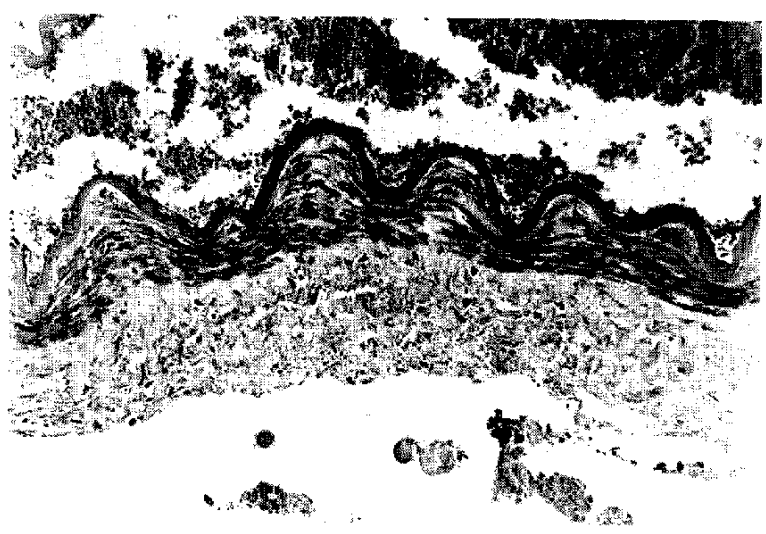

Fig. 2 Microphotograph of the left middlc cerebral artery of Case 1. Necrotic smooth muscle cells are replaced by scattercd, eosinophilic cellular debris. HE stain, $\times 90$. 

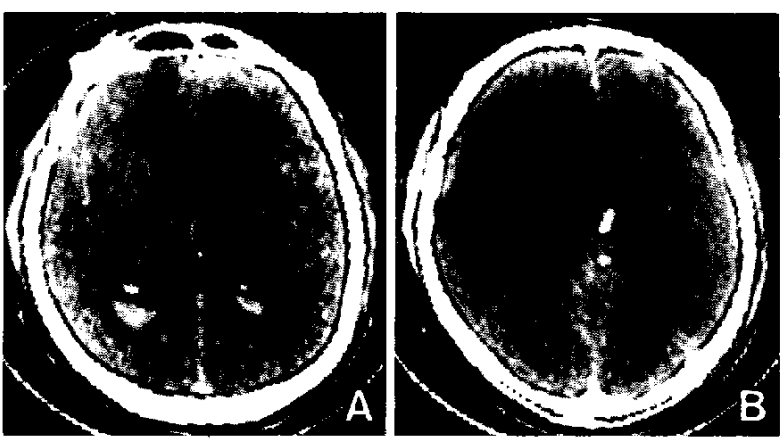

Fig. 3 CT scans in Case 2. A: On the day after $\mathrm{SAH}$, highdensity areas are seen in both bilateral sylvian fissures and occipital horns. B: Nine days after SAH, a lowdensity area is seen in the territory of the left middle cerebral artery.

脈で中等度にみられた。すなわち，中膜の薄い部分では全 層にわたり，また厚い部分では中膜の外煟を主体に筋䇆胞 の核は消头しており，好酸性を示す山形あるいは棈门形の 凝固潒死物質の集皘をみた。 また，中膜筋細胞が壊死を呈 した部分では，内弾性板は平坦化していた。

<症例 $2>39 才$ 才, 男性

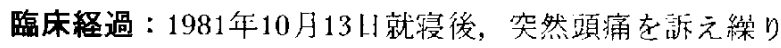

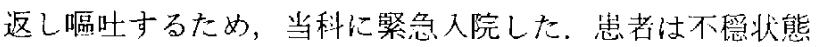
を呈し，両側の硝子体将血がみられ，CT スキャンでは脳 底槽やシルビウス裂なとににクモ膜下出近が認められた。ま た, 発症 2 時閉後に呼吸停止孝伴う再出血発作があった。 翌曰のCT スキャンでは中等度の脳室拡人と脳室内出血と がみられ、シルビウス裂の出血は右よりも左に多かった

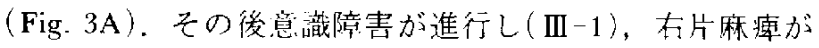
出現したため解角穿刺による胴室一体外ドレナージを行っ たところ，頭蓋內压は $1,000 \mathrm{~mm}$ 水杆を越えていた。術 後，意識レベルは上昇し(I-2)右片麻渒も軽快したが，発 症 1 週間目頃上り再び意識レベルは低下゙し(III-1)，発正10 日日には右片麻庫は增恶した。その際の CT スキャンで は，左中大腷動脈領域は全般に低吸収域を呈し(Fig. 3B)， 左側脳室は圧排され，第三脳空は右へ $5 \mathrm{~mm}$ 偏位してい た。以後，瞳孔不同が出現し，忽者注発拝12日目に死亡し た.

病理所見：脳重は $1,615 \mathrm{~g}$ で, 大脳は特に左半球が湩張 しており，左の鈎回ヘルニアがみられた。无膜下出血 は，視交必槽から脳低槽にかけては多量，左シルビウス㤠 に中等量, 右シルビウス裂に少聂みられ, 出血源は左椎骨 動脈の $3 \mathrm{~mm}$ 大の解離性動脈瘤であった。左:中大脳動脈領 域では軟化が強く，割面ではシルビウス裂に面する側頭葉 と外包において顕著であった。ウイリス輪は全般に強いす

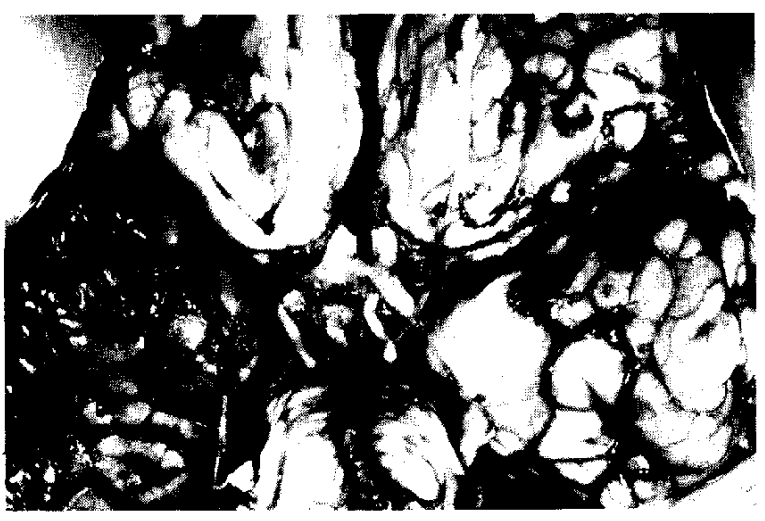

Fig. 4 Basal view of the brain of Case 2 after removal of the clots shows dilatation of the left middle cerebral artery and atherosclerosis of the circle of Willis.

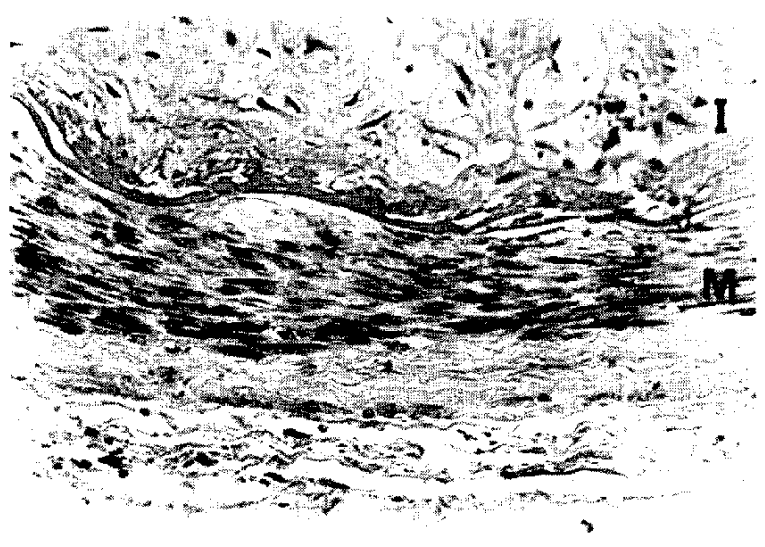

Fig. 5 Microphotograph of the left middle cerebral artery of Case 2. The media (M) is thin, resulting from both atherosclerosis and necrosis of the smooth muscle cells, whereas the intima ( $\mathrm{I}$ ) is thickened. HE stain, $\times 190$.

テローム性硬化を示し，左中人脳動脈は肉眼的に右よりも 㹡張していた(Fig. 4)。アテローム性硬化の強い部分では 内膜の線維性肥厚が著明であり，内弾性板は消失し中膜は

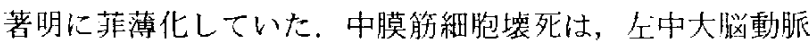
と左椎骨動脈に中等度, 脳底動脈と去後大脳動脈に蛏度に みられた。すなわち，左中大脳動脈では動脈硬化により中 膜は菲薄化しているが，残された少数の中膜筋納胞は好酸 性に染まる短楕们形または紡錻形の㠜湖壤死を示した (Fig. 5).

<症例 3 > 39才, 男性

臨床経過：1982年 4 月 6 日起休後，笑然䫓痛とめまいが 油現し嘔吐した。ただちに某医に入院したが，頭痛は続き 午後になって項部強直が出現し，腰椎穿刺にて代は 230 $\mathrm{mm}$ 水柱で, 髄液は血性を呈した，CTスキャンでは，視 

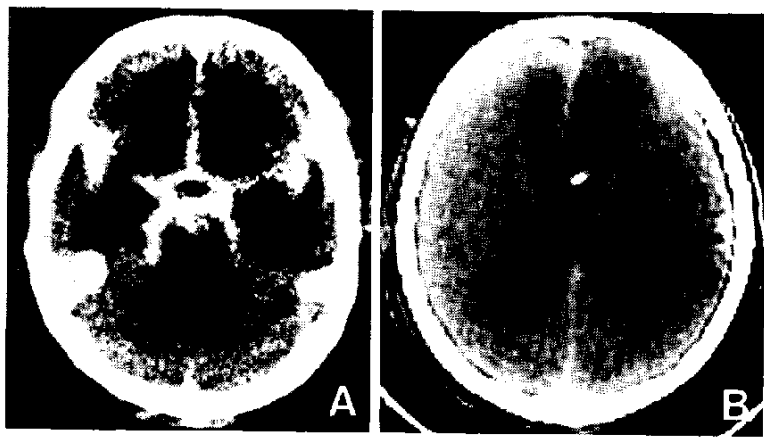

Fig. 6 CT scans in Case 3. A: On the day of SAH, high-density areas are seen in the bilatcral sylvian fissures, interhemispheric fissure, and basal cistern. B: Two weeks after $\mathrm{SAH}$, low-density areas are seen in the territories of both the bilateral anterior cerebral arterics and the right middle cerebral artery.

交叉槽と脳底槽を中心にシルビウス裂や半球間裂などにク モ膜下出血がみられ，脳室采は全般に軽度の航大号した (Fig. 6A)，翌日より患者は軽度の意識障害( II-2)を古し たが，発症 4 日月より意識清明となった。しかし，発症 9 日目上り再び意識障害が出現し，うっ血乳頭がみられ， CTスキャンにて，石前頭葉に低吸収域が出現してきたた め, 脳血管變縮在疑い4月16日当科入転院した。意識障告 (III-1)上左片麻㾝がみら机，岁㒋の Babinski 反身は陽性 であった。ただちに脳宰一体外ドレナージを行い脳血管攣 樎に対する治憭を開始したが，症状注進行性であり4月20 日には除皮貎姿勢を古するようになった。CTスキャンで は，両側特に右䶺大脳動脈領域に明瞭な低吸收域がみら れ，右䫓頂葉內にも一部低吸収域がみられた(Fig. 6B)。 その㣪, 瞳孔侗が出現し, 発痁19日月に死亡した。

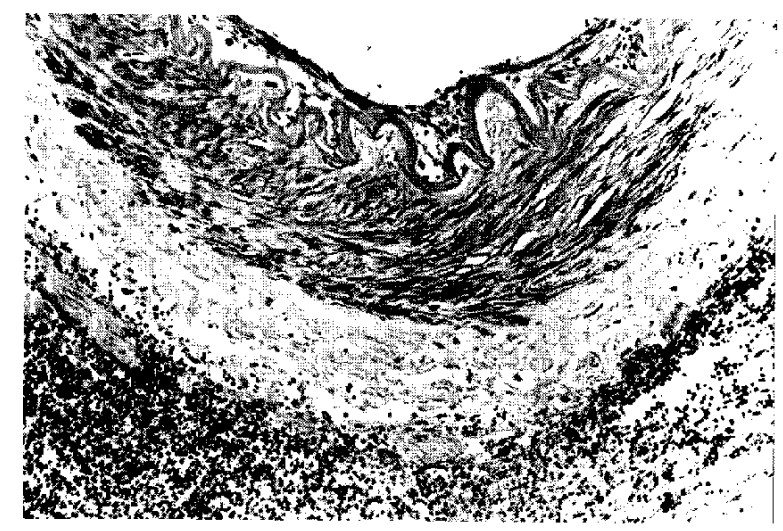

Fig. 7 Microphotograph of the right anterior cerebral artery of Gase 3. Myonecrosis is seen especially in the outer layer of the media. HEs stain, $\times 90$.
病理所見：大脳は全般に隀張しているがやや右半球の腫 张が強く, 右の带状回と鈎回のヘルニアがみられた。モ 膜下出血注，視交文槽に多量，シルビウス裂に中等量，戍爻 底槽に少量みられ，出血源は左後大脳動脈上上小脳動脈に はさまれた $8 \mathrm{~mm}$ 大の脳底動脈瘦であった，台前頭葉上幽 側頭頂葉の軟化が強く，割面では両側の前頭葉に多数の点 状出血認め，両側の側脳室洼特体部付近が压排されて おり，二次的な脳幹出血がみら扎た。両倒前大脳動脈沬半 球間裂部に沁いて明らかな血管徍の左右差を呈し，有のは

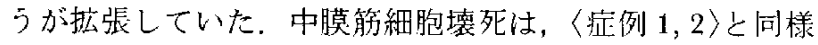
に好酸性で不規則に凝集する凝固壊死として中膜の外層に 優位にみられた（Fig．7)．これらの中膜筇細胞壊死は，右 中大脳動脈に強度に，また左中大脳動脈，雨側前大脳動 脈，ならびに脳底動脈に中等度にみられた。

\section{2. 実験モデル}

中膜筇細胞依死は程度の軽いむのをも含めるとほぼ全例 に羿められ，特に先験 3 日目(Fig. 8A)，6日日(Fig. 8B) の自然死亡犬, および実験 1 週目 (Fig. 8C)，3週目 (Fig. 8D)，7週目の人為的死亡犬に顕著であった。それ らの多くは, 內頸動脈の終未部を初奻, 前大脳動脈や中大 脳動脈の近位部などにみられた。 また，中膜筋細胞壊死が 著明な部分では血管腔は搪張し，内弾性板の平坦化と中膜 の菲薄化がみられた(Fig. 8, Fig. 9B)。中膜筋細胞壊死は 一般に中膜の外層に優位にみられ，㤥や胞体は完全に消失 し帯状の膠原線維束となって掞り(Fig. 8A-C, Fig. 9B)， 一部には核の筋壊後産物と思われる好塭基性顆粒の沈着が みられた。臨床剖検例でみられたような不規則漩集した 好酸性の凝固壊死は人為的死亡人ではみられなか一たが, 自然死亡犬では同様の所見が認められた。すなわち，自然 死亡犬では中膜が壊死をきたした部分は円形，あるいは短 榇円形，紡針形など不規則な形に㠜集した凝固壊死を呈し (Fig. 8B)。 それ以外の部分でも奵酸性の膠原線維束は断 裂していることが多く，人為的死亡犬にみられたような带 状の規則正しい中膜筋細胞㐭死亡は対照的であった。

中膜筋絊胞壊死をきたした脳主幹動脈の周䦸では, クモ 膜下嘧や血管壁などに著明な炎症性病変がみられた（Fig.

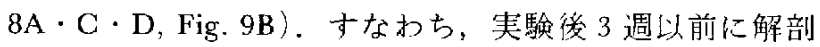
された場合は肉腿的には血管壁泊白調を呈し，3週以降 に解剖された場合は血管壁を含奻周囲のクモ膜卜腔は白濁 ・肥厚していた。 また組織学的には, 実験後 $2 \sim 3$ 週間日 まではクモ膜下腔には少量の出血と人食細泡・形質細胞. 小川形細胞・線維芽細胞などの炎症緗胞が多数みられた (Fig. 8A-G)，一万，実験後 3 週以降注出血队炎症細胞 は減少し，主幹動脈を中心にクモ膜下腔の線維化が進行し ており，増加した膠原線維と血管の外膜が連続しているた 


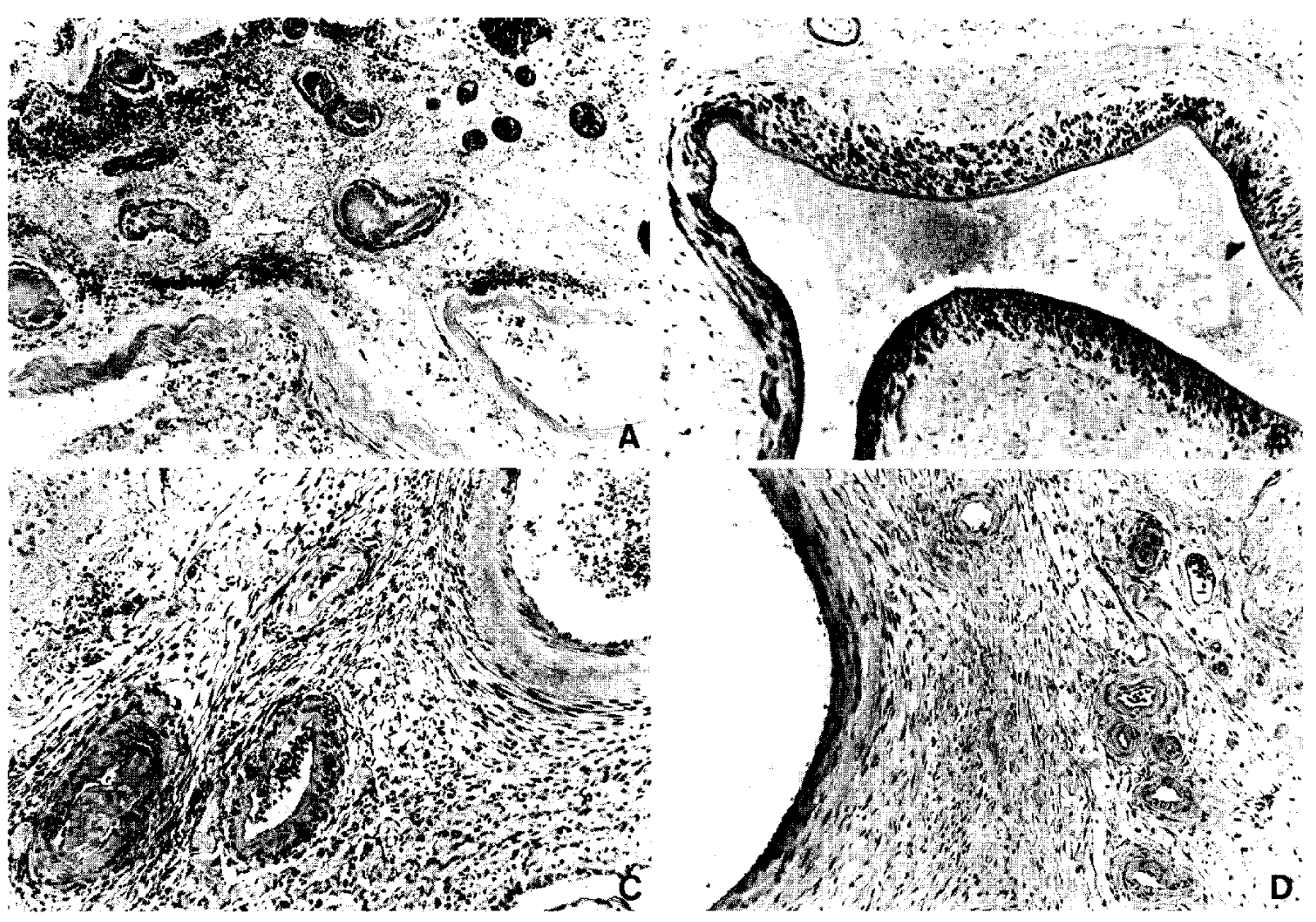

Fig. 8 Microphotographs of the experimental animals that received epinephrine injection into the chiasmatic cistern. A: Dog that died spontaneously 3 days after injection. There is myonecrosis of the large subarachnoid arteries, inflammatory swellings of the small subarachnoid arteries, and numerous red blood cells in the subarachnoid space. HE stain, $\times 100$. B: Dog that died spontaneously 6 days after injection. The necrotic smooth muscle cells are replaced by scattcred, cosinophilic cellular debris. HF. stain, $\times 100$. C: Dog sacrificed 1 week after injection. Myonecrosis is dominant, especially in the outer layer of the media. A mixed population of red blood cells, fibrinoid substance, and inflammatory cells is secn within the swollen wall of small subarachnoid arteries. HE stain, $\times 100$. D: Dog sacrificed 3 weeks after injection. The adventitia can hardly be differentiated from the fibrous tissue, which almost completely obliterates the subarachnoid space. HE stain, $\times 100$.

めに両者を識別しえないこともあった( Fig. 8D)．クモ膜 下腔の炎症发沁が䫓著である失験 3 日月〜3 週間目には， クモ膜下腔の小動脈は著しい肥厚を示し，血管壁には多数 の赤血球や類線維素物質あるいは炎症紲胞などの沈着をみ た(Fig. $8 \mathrm{~A} \cdot \mathrm{C} \cdot \mathrm{D})$.

エピネフリンの視交义慒内注入では，全例に程度の差は あるが，前部視床下部の出血性西るいは虚血性の脳梗塞が みられた(Fig. 9)。脳梗塞は, 中膜胆細胞壞死が強くみら れた 5 頭で特に著明であり， 3 頭は出血性，2 頭は虚血性 の脳梗塞を示した。梗塞部においては, 実験 3 日目に法神 経細胞の壊死(Fig. 9A)，韧鞘の消失ならびにミクログリ アの集積がみられ，実駼 1 週間後には，脂肪を貪食した大 食細胞が多数出現し， axonal swelling や毛細血管の増殖が みられた(Fig. 9B)。一般に, 自然死亡大では人為的死亡
犬よりも視床ト部の梗塞巣が広範网で, 出血の程度が強か った.

\section{IV 考察}

\section{1. 中膜筋細胞壞死の病理}

クモ膜下出血後にみられる中膜筋細胞㐭死の原因として

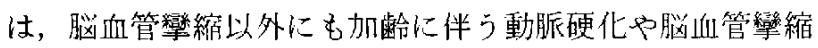
により末梢血管に二次的に生ずる虚血の影響などが考えら

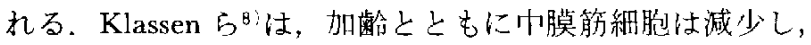
好酸性に染まる線維成分が増加するとし, 小島原ら”も加 夦に伴い外膜側の中膜筋細胞を中心に燷死や変性などが生 ずるとした. Hughes らすは, クモ膜下出血後 3 週間以内 に脍血管攣縮のために死亡した将例には中膜筋細胞壊死が みられると報告したが，彼らが Fig. 3 として示した所兄 


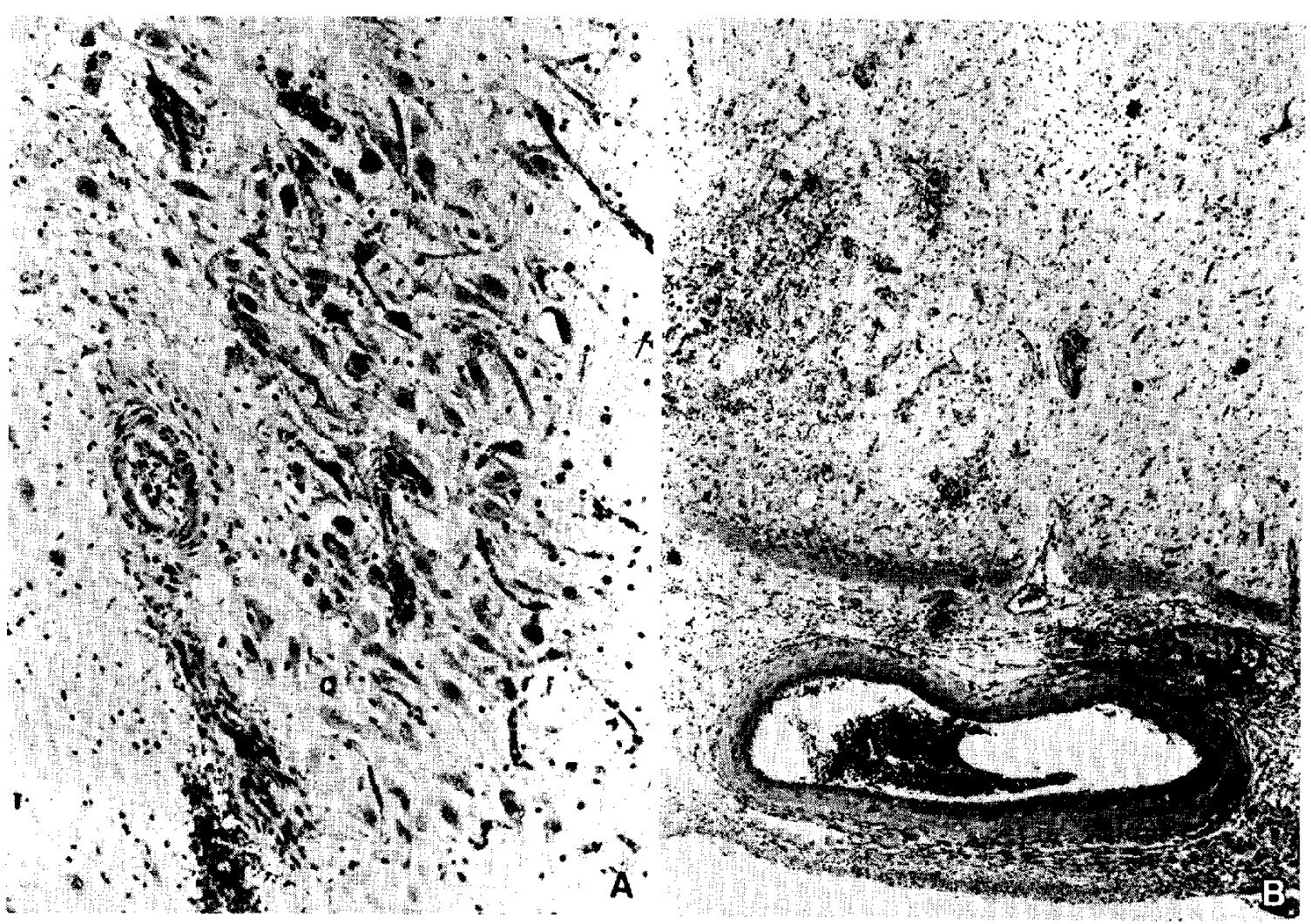

Fig. 9 Microphotographs of the epinephrine-injected animals. A: Dog that died spontaneously 3 days after injection. Neurons of the hypothalamus show necrosis and central chromatolysis associated with hemorrhage. HE stain, $\times 270$. B: Dog sacrificed 1 week after injection. Myonecrosis of the large subarachnoid artery is scen associated with hemorrhagic infarction of the adjacent hypothalamus, which shows accumulation of numerous red blood cells, foamy granular cells, and blood protein, as well as astroglial proliferations. HE stain, $\times 55$.

はこのような動脈硬化性の病变である可能性が強い。ま た，Crompton 3)がFig. 3 に示したクモ膜ト出血のなかに 埋没した小動脈にみられた壊死についても，脳血管熋䈹そ のものによる病変とは考えがたい，純粋に脸血管摹縮に起 因する中膜筋細胞坮死を報告したのは Mizukami ら り，クモ膜下出侐後 2 週間を過ぎると脳向管攣縮を嘋した 血管は中膜が笳細胞壊死により菲薄化し，血管内腔は拡張

\section{しているとした。}

奏験動物に捛いて中膜筋細胞壊死を作製するこ上は，上 りむなおさずヒトの脳血管卛縮を再現することであるた め，これまで多くの研究がなされてきた。すなるち，Fein ら 脳血管攣縮在作製し，電䫓的に中膜筋細胞の空胞化や濃染 像，および細胞内器官の変性像などをみた。また Alksne ら ば，サルの脸底槽に $2 \mathrm{mg}$ の norepinephrine を注入す ることにより二相性の脸血管攣縮在作製し，電影的に筋綵 維の変性や消失, 紐胞膜の融解さらに高電子密度の封入体
の出現などの所見索観察した。さらにTani ら の視交文槽に動脈血や norepinephrine 在注入することによ り，電顕的に中膜筋細胞の一部に壊死像をみた。最近 Liszczak ら ${ }^{10}$ は，イヌの大槽内に48時間の間隔で各 $4 \mathrm{ml}$ の自家血注入することによりヒトの脳血管攣縮に似た夹 験モデルを作製し，電顕的には中膜笳細胞壊死の初期像が みられるとした。これらの研究者が作製した筋細胞壊死 は，以ずれも中膜笳細胞のごく一部に限定されたもので， しかも電子顕微鏡でしか観察することができない.

Peerless ら ${ }^{14}$ は，臨床剖検例と奏験モデルとでは脳血管 攣縮による血管病変に本質的な差異はないが，その程度に は者しい差異があり，後者の病変汢前者のそれよりもはる かに軽微であるとした，最近我々 ${ }^{19}$ は，イヌの視交皮槽に エピネフリンを注入することにより，臨床剖検例と同程度 のしかも光影で観察し 5 る中膜笳細胞の広沉な壊死を作製 寸ることに成功した，そこで，本論文において臨床剖検例 でみられた中膜笳細胞壊死亡实驗モデルでみられたそれと 
を光顕的に比較検䚺した。本論文で供覧した臨林剖険例 は、いずれも脳血管攣縮が直接の死风となった典型例であ り，組織学的に注 3 症例之屯中膜の外層に厦位な筋細胞壊 死がみられた，すなわち，中膜筋細胞の核注消失し，代り

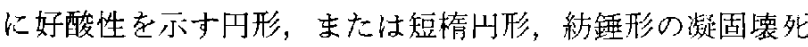
がみられ，凝固壞死の強い部分では内弾性板の平坦化や中 膜の翡薄化さらに血管内腔の摭涱などがみられた。一方， 実験モデルにおいては，中膜筋細胞壊死注人為的死亡犬上 自然死亡犬とでは樣相を異にしておう，中膜筋細胞壊死の 部分は人為的死亡犬では带状を堊する膠原線維束となって いたのに対し，自然死亡犬では膠原線維間が不規則汇断裂 し，臨床剖㛟例と同様に散在性に凝集する凝固壊死状上な つていた．自然死亡犬では人為的死亡犬と比べると死戦期 が長く、また死亡から剖検までの特間的な羊れがあったた めに自己融解が進み，線維化の所見が修飾されたもの上思 われた。したがって，臨床剖検例でみられた俔則に凝集 寸る中膜筋細胞の壊死像についても，死戦期に進行寸る日 己融解や死缓変化の影響があるものと推定された。

\section{2. 脳血管揫縮の成因}

脳血管攣縮が発現するために多星のクモ膜ト出血が不可 火であることは，今同の臨床剖娭例からも明らかである。

しかし，実駼動物のクモ膜下腔に血液を注入するだけでは 光影的に認めうる中膜筋細胞壊死は作製しえず，エピネフ リンの単独注入により臨床剖検例と同様の所見を作製しう るという事実 ${ }^{19}$ は，脳血管攀縮の発垷，維持には血液以外 にいるいるな要因が関与していることを示㖫している。

脳血管攣縮は，前交通動脈瘤や内颈後交通動脈瘤などウ イリス輪の前半部に生ずる動脈瘤の破裂によるものが多 く，これらは特に前部視床下部の穿通枝を損傷する危険が 大きい，またクモ膜下出血後には，高咶厈や不整脈，心電 図の異常など交感神経系の興奮を示咬する䠛床症状がみら れる. Neil-Dwyer ら ${ }^{13}$ は, クモ膜下出血では発症後 2 週 間にわたり，特に出血当日扔よび第 2 週比扔いて果中力テ コラーミン值が高いとし， Benedict $ら^{2)}$ もクモ膜下出血後 の症例では血清カテコラーミンが高值を示寸とした。

Doshi $ら^{4)}$ は，クモ膜下出血の剖検例に扔いて視床下部と 心筋の両者に組織病变を㤎めた。今回の奏験でも，著明な 中膜筋䋖胞壊死がみられたイ又には，必ず前部視床下部の 脳㤦塞が合併していた。 それでは，脳血管攣縮の発現に視 休ト部の障害はどのような役割りを果すのであろうか。 Wilson (1) $^{18}$ は，イヌのクモ膜卜腔に視床下部の抽出物を 注入すると，長時間持続する脑血管卛維が牛ずることよ り，視床下部にはプロスタグランディンFやカテコラー ミンなどの血管作動物質が含まれていると推定した。一方 Wilkins $^{17}$ は，前部視床下部の障害により交感神経の中枢
である後部視休下部が優位となり，交感神経系の興奮と副 惄からのカテコラーミンの分泌増加が生ずるために脸血管

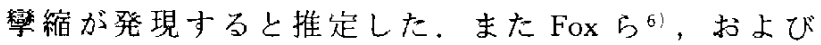
Mizukami ら"1:は，クモ膜下出血後数日以内に造影剂を静 注してCTスキャンを行うと, ウイリス輪の周囲に造影剂

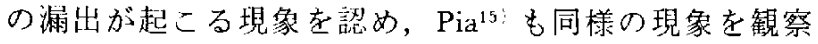
し，クモ膜下出血㣪には血液一㵦液関門の破綻が牛ずる上 した.

以上の事奉より，クモ膜下出血徭に增加した血中のカテ コラーミンは，クモ膜下腔に持続的に漏出しているむの上 推定される，今回の尖験モデルでは，エピネフリン注入後 3 週問目まで, クモ膜下腔の小動脈の血管壁には多数の尗 血球や類線維素物犋あるい沙症繧胞などが沈着して打 ク，この所見はこれら小動脈からの血液成分の漏出を示检 していた．エピネフリンが臨床剖検例に多られるのと同様 の中膜笳細胞壊死を惹起した理由として，以下のことが推 定される，すなわち，奏験当初エピネフリンはウイリス輪 にきわめて強度の攣縮をもたらすと同時に，前部視休下゙部 の穿通枝にも強度の攀縮をもたらし，したがって前部視林 下部は脳梗塞をきたしたために後部視床下部が優位々な り，血中のカテコラーミンが増加した。ささらに，ク无膜下 腔の小動脈の變縮により二次的な血管壁の透過性六進が生 じ，血中に増加したカテコラーミンがウイリス輪の周辺に 持続的に漏出するために強度の脳血管攣縮が続き，中膜筋 細胞は壊死をきたした。もちろん，視床下部の梗塞後産物 が脳血管攣縮の原因となっていたとも考えられる，脸血管 攣緶が一般に $1 \sim 2$ 週間続いたのちに自然宽解するのは， 長時間統いた攣縮により小動脈の血流が減少するためカテ コラーミンなどの血液成分の漏出が緦えるのと同時に，視 床下部の病変が器質化の時期に入るためであるう。さら に，中膜の外層上り筋細胞壊死が進行するに従って中膜筋 紲胞の絶対数が減少し，物理的に血管攣縮を維持すること が不可能となることも考えられる。

\section{$\mathrm{V}$ 結 語}

クモ膜下出血後に致死的な脳血管攣縮を合併した臨休剖 娭 3 例と，イヌの視交冬槽にエピネフリンを影入して作製 した脳血管攣縮の実験モデル10例とを病理学的に比較検討 し，以下の結論を得た。

1. 臨床剖検例では，攣縮をきたした血管は中膜が菲薄 化し，外層に優位な筋細胞壊死がみられた。すなおち，中 膜筋細胞は核が消失し，不規則に㠜集した好酸性の凝固溗 死を呈した。

2. 実験モデル犬では，視休ト部の梗塞巣とクモ膜下腔 の小動脈の炎症性肥涅を合併した 5 例において，特に著明 
な中膜筋細胞壊死がみられた。

3. 人為的死亡犬と自然死亡犬とでは中膜筋細胞塝死は 椂相を異にし，前者では耑状の膠原線維束が，後者では臨 床剖娭例と同様の凝固壊死がみら扎た。

4. 脳血管變縮徭に生ずる中膜筋細胞壊死の原风として は，エピネフリンのみならず，視休ト部の梗塞巣やクモ膜 下腔の小動脈壁から持続的に漏出する血管作動物質が重要 な動きをなすものと推定された。

\section{文献}

1) Alksne JF, Greenhoot JH: Experimental catecholamine-induced chronic cerebral vasospasm. Myonecrosis in vessel wall. J Neurosurg 41: 440-445, 1974

2) Benedict $\mathrm{CK}$, Loach AB: Clinical significance of plasma adrenaline and noradrenaline concentrations in patients with subarachnoid haemorrhage. J Neurol Neurosurg Psychiatry 41: 113117,1978

3) Crompton MR: The pathogenesis of cerebral infarction following the rupture of cerebral berry aneurysms. Brain 87: 491-510, 1964

4) Doshi R, Neil-Dwyer G: Hypothalamic and myocardial lesions after subarachnoid hemorrhage. $J$ Neurol Neurosurg Psychiatry 40 : $821-826,1977$

5) Fein JM, Flor WJ, Cohan SL, Parkhurst J: Sequential changes of vascular ultrastructure in experimental cerebral vasospasm. Myonecrosis of subarachnoid arteries. J Neurosurg 41: 49-58, 1974

6) Fox JL, Ko JP: Cerebral vasospasm: A clinical observation. Surg Neurol 10: 269-275, 1978

7) Hughes JT, Schianchi PM; Cerebral artery spasm. A histological study at necropsy of the blood vessels in cases of subarachnoid hemorrhage. $J$ Neurosurg 48: 515-525, 1978

8) Klassen AC, Sung JH, Stadlan EM: Histological changes in cerebral arteries with increasing age. $J$ Neuropath Exp Neurol 27: $607-623,1968$

9）小島原將保，大根田玄青：血管の病理と老化．細胞 11:
$610-618,1979$

10) Liszczak TM, Varsos VG, Black PM, Kistler JP, Zervas NT: Gerebral arterial constriction after experimental subarachnoid hemorrhage is associated with blood components within the arterial wall. $J$ Neurosurg 58: 18-26, 1983

11) Mizukami M, Kawase T, Tazawa T, Nagata K, Yunoki K, Yoshida Y: Hypothesis and clinical evidence for the mechanism of chronic cerebral vasospasm after subarachnoid hemorrhage, in Wilkins RH (ed): Cerebral Atterial Spasm. Baltimore, Williams \& Wilkins, 1980, pp 97-106

12) Mizukami $M$, Kin $H$, Araki G, Mihara $H$, Yoshida $Y$ : Is angiographic spasm real spasm? Acta Neurochir (Wien) 34: 247259, 1976

13) Neil-Dwyer G, Cruickshank J, Stott A, Brice J: The urinary catecholamine and plasma cortisol levels in patients with subarachnoid haemorrhage. J Neurol Sci 22: 375-382, 1974

14) Peerless SJ, Kassell NF, Komatsu K, Hunter IG: Cerebral vasospasm: Acute proliferative vasculopathy? II. Morphology, in Wilkins RH (ed): Cerebral Aterial Spasm. Baltimore, Williams \& Wilkins, 1980, pp 88-96

15) Pia HW: Aneurysm surgery-grading and timing, in Sano $K$ (ed): Neurosurgeons: Proceedings, First Annual Meeting of the Japanese Congress of Neurological Surgeons. Tokyo, 1982, pp 89-104

16) Tani E, Yamagata S, Ito Y: Intercellular granules and vesicles in prolonged cerebral vasospasm. J Neurosurg 48: 179-189, 1978

17) Wilkins RH: The possible role of the hypothalamus in the development of intracranial arterial spasm, in Wilkins RH (ed): Cerebral Arterial Spasm. Baltimore, Williams \& Wilkins, 1980, pp 266-269

18) Wilson JL, Feild JR: The production of intracranial vascular spasm by hypothalamic extract. $J$ Neurosurg 40: 473-479, 1974

19) Yamashima T, Yamamoto S: Cerebral arterial pathology in experimental subarachnoid hemorrhage. $J$ Neurosurg 58: 843-850, 1983

〔別刷請求先 : $\mathbf{\top} 920$ 金沢书宝町13-1, 金泪大学脳神経外科, 山嶋哲盛了 